\title{
ПРИОСТАНОВЛЕНИЕ ПРОИЗВОДСТВА ПО УГОЛОВНОМУ ДЕЛУ В СВЯЗИ С ОБРАЩЕНИЯМИ ЕГО УЧАСТНИКОВ В КОНСТИТУЦИОННЫЙ СУД РОССИЙСКОЙ ФЕДЕРАЦИИ
}

Аннотация: Автор анализирует уголовно-процессуальные последствия обращения участников уголовного судопроизводства - суда и участников со стороны защиты - в Конституционный Суд Российской Федерации соответственно с запросом о проверке конституционности закона, подлежащего применению в деле, и жалобами на нарушение конституционных прав и свобод положениями закона, примененными в конкретном деле. Данные последствия состоят в приостановлении производства по уголовному делу (материалу, рассматриваемому в порядке уголовного судопроизводства), однако отличаются моментом приостановления: в связи с направлением запроса любое уголовно-процессуальное производство приостанавливается тут же, а в связи с направлением жалобы - лишь кассационное и надзорное и после принятия данной жалобы Конституционным Судом к рассмотрению. Методологической основой исследования выступила доктрина судебного права - возрождающаяся в настоящее время общая теория судебной власти и процессуального права, позволяющая проводить междисииплинарные исследования в сфере правосудия. Автор, опираясь на зарубежный опыт Австрии и Андорры, предлагает оптимизировать уголовно-процессуальную форму приостановления производства по делу, признавая его обязательным в каждом случае направления запроса, но не абсолютным с точки зрения осуществления процессуальных действий. При таком подходе после направления запроса в Конституционный Суд РФ суд может осуществлять процессуальные действия, не связанные с применением нормы права, конституционность которой оспорена в запросе.

Ключевые слова: Конституционный Суд РФ, уголовный прочесс, взаимосвязь видов судопроизводства, доктрина судебного права, суд общей юрисдикции, запрос суда, конституционная жалоба, приостановление, уголовное дело, конституционный судебный процесс

DOI: 10.7256/1994-1471.2014.3.11100

3 ащита прав граждан в Конституционном Суде Российской Федерации (далее - Конституционный Суд) и конституционных (уставных) судах субъектов Российской Федерации входит в состав целостной системы судебной защиты прав и свобод человека и гражданина. Механизм конституционного судопроизводства связан с другими элементами системы судебной защиты прав и свобод другими видами судопроизводства. Одной из «точек соприкосновения» конституционного и уголовного судопроизводств является ин-

ститут приостановления производства по уголовному делу в связи с обращениями его участников в Конституционный Суд Российской Федерации. Взаимосвязь конституционного и уголовного судопроизводств в данном вопросе обусловлена использованием лицом для своей защиты одновременно и конституционного и уголовного судопроизводств, разница в использовании которых объясняется способом нарушения защищаемых в рамках данных видов судопроизводства прав: конституционное судопроизводство направлено на защиту от

(c) Соколов Тимур Викторович

* Ассистент кафедры государственного и административного права, Санкт-Петербургский государственный университет

[tvs_2008@mail.ru]

190000, г. Санкт-Петербург, Сенатская площадь, д. 1.

Статья выполнена при финансовой поддержке Российского гуманитарного научного фонда в рамках проекта проведения научных исследований№ 12-33-01232 на тему «Формы взаимосвязи конституционного и уголовного судопроизводств в контексте доктрины судебного права». 
нарушений на нормативном уровне правового регулирования общественных отношений, а уголовный процесс призван защищать права человека в плоскости фактических отношений.

В Конституционный Суд могут обратиться суд общей юрисдикции с запросом о проверке конституционности закона, подлежащего применению в конкретном деле (далее - запрос суда), а иные участники - с жалобой на нарушение конституционных прав и свобод положениями закона, примененными в конкретном деле. В данный круг участников уголовного процесса не входят, пожалуй, лишь государственные органы и их должностные лица, в чьем производстве находится уголовное дело (прокурор, за исключением Генерального прокурора РФ, руководитель следственного органа, следователь и дознаватель), все остальные участники уголовного судопроизводства, включая физических и юридических вне зависимости от их уголовно-процессуального статуса и выполняемых ими уголовно-процессуальных функций, в данном праве представляются не ограниченными. Однако последствия реализации данными субъектами своих правомочий различны.

Статья 98 Федерального конституционного закона от 21 июля 1994 г. № 1-ФКЗ «О Конституционном Суде Российской Федерации» (в редакции Федерального конституционного закона от 5 апреля 2013 г. № 1-ФКЗ) (далее Закон о Конституционном Суде) определяет, что Конституционный Суд Российской Федерации, приняв к рассмотрению жалобу на нарушение законом конституционных прав и свобод граждан, уведомляет об этом суд, принявший последнее судебное постановление по делу заявителя, в котором применен обжалуемый закон, а по требованию заявителя - орган, осуществляющий в соответствии с федеральным законом исполнение данного судебного постановления, и суд, рассматривающий дело, для которого данное судебное постановление может иметь значение; соответствующий суд может приостановить исполнение судебного постановления или производство по делу до принятия Конституционным Судом Российской Федерации постановления. Из этой нормы следует, что приостановление производства по делу заявителя является правом суда, а не его обязанностью.

Статья 103 Закона о Конституционном Суде, предусматривая, что в период с момента вынесения решения суда об обращении в Конституционный Суд Российской Федерации и до принятия постановления Конституционного Суда Российской Федерации производство по делу или исполнение вынесенного судом по делу решения приостанавливаются, определяет обязательность приостановления производства по делу.
Уголовно-процессуальное законодательство идет по иному пути: п. 3 ч. 2 ст. 238 Уголовнопроцессуального кодекса Российской Федерации от 18 декабря 2001 г. № 174-Ф3¹ (далее - УПК) устанавливает, что судья выносит постановление о приостановлении производства по уголовному делу в случае направления судом запроса в Конституционный Суд или принятия Конституционным Судом к рассмотрению жалобы о соответствии закона, примененного или подлежащего применению в данном уголовном деле, Конституции Российской Федерации. Очевидно, что отраслевая норма делает приостановление обязательным вне зависимости от вида обращения, повлекшего приостановление. Соответственно, между нормами разной юридической силы имеется коллизия по вопросу обязательности приостановления производства в связи с принятием Судом к рассмотрению жалобы гражданина.

Данная коллизия породила и дискуссию по данному вопросу на страницах печати. Так, М.С. Егорова и А.А. Сеньков в уголовно-процессуальной науке и А.А. Аношина и Е.А. Иванова в науке гражданского процесса полагают, что приостановление производства в двух данных случаях является не обязательным, есть факультативное основание к приостановлению производства по делу, а решение вопроса о приостановлении относится к сфере дискреции правоприменителя, т.е. суда. ${ }^{2}$

В решении данной коллизии представляется необходимым исходить из следующего. В случаях использования лицом для защиты своих прав одновременно двух видов судопроизводства (в нашем случае - конституцион-

\footnotetext{
Приостановление производства по уголовному делу возможно лишь в тогда, когда уголовное дело (материал, рассматриваемый в порядке уголовного судопроизводства) находится в производстве суда. На других этапах производства, в том числе досудебных стадиях уголовного процесса, приостановление невозможно в принципе, поскольку жалоба гражданина не может быть принята к рассмотрению Конституционным Судом, поскольку она не отвечает такому критерию допустимости, как завершение производства по делу заявителя (п. 2 ст. 97 Закона о Конституционном Суде).
}

Егорова М.С. Институт приостановления производства по уголовному делу и обеспечение прав и законных интересов участников уголовного процесса при реализации его норм: Автореф. дисс. ... канд. юрид. наук. Волгоград, 2003. - С. 9, 14-16; Сеньков А.А. Отложение и приостановление судебного разбирательства как общие условия: Автореф. дисс. ... канд. юрид. наук. - Челябинск, 2011. - С. 11, 22, 25; Аношина А.А. Приостановление производства по гражданским делам в судах общей юрисдикции: Автореф. дисс. ... канд. юрид. наук. Саратов, 2006. - С. 8, 21, 24; Иванова Е.А. Применение норм Конституции Российской Федерации в гражданском судопроизводстве: Автореф. дисс. ... канд. юрид. наук. - М., 2009. - С. 11, 20-21. 
ного и уголовного) может возникнуть конкуренция способов судебной защиты, чреватая вынесением разными судами по одному и тому же (для физического лица) вопросу двух противоположных по содержанию и правовым последствиям решений, а потому средством предотвращения названных коллизий является приостановление одного из судопроизводств. Отсюда само по себе приостановление призвано не допустить отрицательных последствий применения неконституционных норм. Применительно к запросу суда это правило признано законодателем: суд должен воздержаться от применения норм, которые им же и оспорены. С жалобой гражданина представляется аналогичная ситуация: принятие жалобы к рассмотрению свидетельствует о наличии основания, которым является неопределенность в вопросе соответствия отраслевых норм Конституции (ч. 2 ст. 36 Закона о Конституционном Суде). Поскольку поставлена под сомнение конституционность нормы принятием обращения к рассмотрению, то суды, в чьем производстве находится дело заявителя, в любом случае должны воздержаться от применения оспоренных норм с тем, чтобы предотвратить негативные последствия применения неконституционных норм.

Практике Конституционного Суда известен случай, когда после принятия им жалобы к рассмотрению по делу заявителя принимались уголовно-процессуальные решения, в том числе отменяющие судебные решения, основанные на нормах права, признанных позднее неконституционными, что, по сути, влечет утрату жалобой свойств допустимости. Так, 20 июня 2012 г. Конституционным Судом в соответствии с требованиями статей 42, 96 и 97 Закона о Конституционном Суде была принята к рассмотрению в заседании с проведением слушания жалоба гражданина С.А. Красноперова, а 7 сентября 2012 г. президиум Приморского краевого суда в качестве суда надзорной инстанции по надзорному представлению заместителя прокурора Приморского края от 24 июля 2012 года вынес постановление, которым отменил вступившее в законную силу постановление мирового судьи судебного участка № 47 города Находки Приморского края от 20 апреля 2012 г. и направил материалы по заявлению С.А. Красноперова на новое рассмотрение суда первой инстанции.

Конституционный Суд отметил в своем постановлении одну сторону проблемы: возобновление производства в суде общей юрисдикции после того, как судебное решение вступило в законную силу, не означает, что жалоба С.А. Красноперова утратила свойство допустимости: поскольку неопределенность в вопросе о конституционности оспариваемых им норм может быть устранена только в ходе конституционного судопроизводства, а уголовное дело по заявлению заявителя (уголовно-процессуальный способ защиты прав заявителя) до момента вынесения постановления (16 октября 2012 г.) не возбуждено, Конституционный Суд посчитал необходимым подтвердить допустимость жалобы С.А. Красноперова и рассмотреть дело по этой жалобе в заседании с проведением слушания. ${ }^{3}$

Здесь же усматривается и иной аспект проблемы, не нашедший своего отражения в названном постановлении: неприостановление производства по уголовному делу создаст больше проблем, нежели приостановление, которое лишь увеличит длительность производства по делу; одной из таких проблем будет являться необходимость отмены судебных решений, принятых судами общей юрисдикции после принятия Конституционным Судом жалобы к рассмотрению, при условии, что они приняты на нормах, признанных Судом в последствии неконституционными.

Кроме того, нельзя не учитывать, что граждане избирают конституционное судопроизводство в качестве средства судебной защиты, как показывает практика, одновременно с обращением в суд кассационной или надзорной инстанции, указывая в своих обращениях о нарушении одних и тех же прав (с учетом того, что эти права нарушаются различным образом). Следовательно, Конституционному Суду и суду общей юрисдикции кассационной или надзорной инстанции придется оценивать практически одни и те же обстоятельства, что чревато возможным расхождением этих судов в своих выводах. Для предотвращения таких «разночтений одних и тех же обстоятельств и одних и тех же норм права», как видится, и необходимо приостановление уголовного судопроизводства.

Следовательно, приостановление производства по уголовному делу в связи с возбуждением конституционного судопроизводства должно являться обязательным как в случае направления запроса суда, так и в случае принятия Конституционным Судом к рассмотрению жалобы гражданина.

Поскольку обращение суда общей юрисдикции с запросом возможно в любой судебной стадии и в любом судебном производстве, то будет

\footnotetext{
3 Постановление Конституционного Суда Российской Федерации от 16 октября 2012 года № 22-П по делу о проверке конституционности положений части второй статьи 2 и части первой статьи 32 Уголовно-процессуального кодекса Российской Федерации в связи с жалобой гражданина С.А. Красноперова // Собрание законодательства Российской Федерации. - 2012. - № 44. - Ст. 6071.
} 
приостановлена процессуальная деятельность в той стадии и в том уголовно-процессуальном производстве, в котором произошло обращение с запросом. О приостановлении производства по делу суд общей юрисдикции выносит определение, принимаемое после собственно направления запроса в Конституционный Суд. Следовательно, основанием приостановления уголовного процесса является сам факт направления запроса в Конституционный Суд, т.е. юридический факт уголовно-процессуального происхождения.

Приостановление уголовного судопроизводства в связи с жалобой гражданина имеет иное основание - принятие данной жалобы Конституционным Судом к рассмотрению, о чем в суд общей юрисдикции сообщает судья Конституционного Суда, являющийся судьейдокладчиком по данному делу (принятие жалобы к рассмотрению влечет возбуждение в Суде дела, которое условно можно именовать конституционным). Поскольку жалоба допустима лишь при условии применения закона в отношении заявителя в его деле и при завершении в суде производства по делу заявителя (ст. 97 Закона о Конституционном Суде), принятие жалобы к рассмотрению влечет приостановление лишь судебных производств по проверке правосудности судебных решений, вступивших в законную силу, т.е. лишь кассационного и надзорного производств, а также всех судебных производств в стадии исполнения приговора (при условии, что принята жалоба, в которой оспариваются законоположения, регламентирующие предшествующие стадии и не распространяющиеся на стадию исполнения приговора).

В данном аспекте заслуживает обсуждения вопрос: может ли приостановление производства по делу, будучи обязательным, быть не абсолютным? Приостановление производства по делу состоит в невозможности совершения процессуальных действий до возобновления производства. Современный законодатель установил абсолютный запрет на совершение каких-либо процессуальных действий по приостановленному уголовному делу. Между тем, такое приостановление, будучи обязательным, представляется неабсолютным: суд, направивший запрос, может производить действия и принимать решения, не связанные с применением оспоренных в запросе норм. Конституционно-судебное законодательство зарубежных стран - ч. 2 ст. 63 Закона о Конституционном Суде Австрии ${ }^{4}$ и ч. 2 ст. 55 Закона о Конститу-

4 Constitutional Court Act 1953 (Verfassungsgerichtshofgesetz). - URL: vfgh.gv.at/cms/vfgh-site/english/downloads/ englishvfgg.pdf. ционном трибунале Андорры ${ }^{5}$ - знает нормы, позволяющие обычным судам после направления запросов в центральные органы конституционной юстиции совершать процессуальные действия, не связанные с разрешением по существу судебного дела.

Рациональное зерно таких положений состоит в том, что они обеспечивают реализацию принципа процессуальной экономии, предоставляя суду возможность совершать действия и принимать решения, не связанные с применением норм права, оспоренных в запросе суда. Следовательно, приостановление процесса, будучи обязательным, может быть неабсолютным: после направления запроса суды различных инстанций могут принимать лишь те процессуальные решения, которые не связаны с разрешением дела по существу, воздерживаясь при этом от применения норм права, конституционность которых оспорена в запросе. Например, суд может разрешать промежуточные процессуальные вопросы - о применении мер принуждения, обеспечения и др., либо же исследовать доказательства по другим эпизодам обвинения. На необходимость решения одного из таких вопросов указывает Пленум Верховного Суда Российской Федерации в постановлении от 31 октября 1995 г. № 8 «0 некоторых вопросах применения судами Конституции Российской Федерации при осуществлении правосудия»: если подсудимый содержится под стражей, рекомендовать суду в каждом таком случае обсуждать вопрос об изменении ему меры пресечения. ${ }^{6}$

Сроки приостановления различны, поскольку по-разному определяется момент начала приостановления производства по делу.

Запрос суда влечет приостановление уголовного судопроизводства с момента его направления; жалоба же гражданина влечет приостановление уголовного процесса с момента ее принятия Конституционным Судом к рассмотрению. Общей чертой этих сроков является момент окончания. Законодательно этот момент не определен. Между тем, таким моментом представляется момент вынесения Конституционным Судом своего решения по существу обращения. Такими решениями мо-

Andorra «Qualified Law» on the Constitutional Court (Loi Qualifiee du Tribunal Constitutionnel). - URL: www. tribunalconstitucional.ad/docs/legislacio/en/lqtc.pdf.

6 Постановление Пленума Верховного Суда Российской Федерации от 31 октября 1995 г. № 8 «О некоторых вопросах применения судами Конституции Российской Федерации при осуществлении правосудия» (в ред. Постановления от 16 апреля 2013 г. № 9) // Бюллетень Верховного Суда Российской Федерации. - 1996. - № 1; 2013. - № 6 . 
гут выступать определение об отказе в принятии запроса суда к рассмотрению, определение о прекращении производства по делу или постановление Суда.

Данные выносимые решения достаточно оперативно доводятся до сведения участников конституционного судопроизводства путем направления им копий этого решения, официальной публикации решения в известных источниках, а также размещения решения на сайте Суда в сети Интернет. Все данные способы являются официальными и обеспечивают достоверность размещенной информации. Таким образом, можно пойти по пути признания того, что ознакомление суда общей юрисдикции с одним из трех указанных источников создает основание для возобновления приостановленного производства по уголовному делу. Однако такой подход отчасти противоречит принципу пето јudex sine actore, поскольку вынуждает суд самому искать информацию о его запросе или жалобе гражданина. Следовательно, справедливым будет считать, что производство по уголовному делу подлежит возобновлению только после получения судом общей юрисдикции сопроводительного письма, с которым Конституционный Суд (вернее, руководитель Секретариата Суда) препровождает официально заверенную копию решения Конституционного Суда.

Современное правовое регулирование вопросов компенсации за нарушение права на судопроизводство в разумный срок или права на исполнение судебного акта в разумный срок, ${ }^{7}$ а именно названный Федеральный за- кон и постановление Пленума Верховного Суда Российской Федерации и Пленума Высшего Арбитражного Суда Российской Федерации от 23 декабря 2010 года № 300/64 «0 некоторых вопросах, возникших при рассмотрении дел о присуждении компенсации за нарушение права на судопроизводство в разумный срок или права на исполнение судебного акта в разумный срок» не содержат какой-либо регламентации по поводу учета периода, на который было приостановлено производство по делу в связи с обращением участников уголовного судопроизводства в Конституционный Суд.

Тем не менее, учитывая длительность рассмотрения обращений в Конституционном Суде, следует выработать правила учета этих периодов в общей продолжительности производства по уголовному делу и оценки ее как разумного срока уголовного судопроизводства. В практике Европейского Суда по правам человека выработаны правила учета поведения стороны для оценки разумности срока уголовного судопроизводства, в том числе связанные с поведением заявителя. ${ }^{8}$ Проецируя данные правила на рассматриваемую нами ситуацию, можно выработать следующий критерий для решения вопроса о разумности срока уголовного судопроизводства: период, на который было приостановлено производство по уголовному делу, должен исключаться из общей продолжительности срока судопроизводства, если инициатива на обращение в Суд исходила от сторон; если же инициатором запроса был сам суд - такое исключение недопустимо.

\section{Библиография}

1. Аношина А.А. Приостановление производства по гражданским делам в судах общей юрисдикции: Автореф. дисс. ... канд. юрид. наук. - Саратов, 2006.

2. Егорова М.С. Институт приостановления производства по уголовному делу и обеспечение прав и законных интересов участников уголовного процесса при реализации его норм: Автореф. дисс. ... канд. юрид. наук. - Волгоград, 2003.

3. Иванова Е.А. Применение норм Конституции Российской Федерации в гражданском судопроизводстве: Автореф. дисс. ... канд. юрид. наук. - М., 2009.

4. Никитина А.В. Разумный срок судебного разбирательства и исполнения судебных актов: практика получения справедливой компенсации: Монография / Отв. ред. С.В. Нарутто. - М.: Норма; ИНФРА-М, 2012.

\footnotetext{
Федеральный закон от 30 апреля 2010 г. № 68-Ф3 «О компенсации за нарушение права на судопроизводство в разумный срок или права на исполнение судебного акта в разумный срок» // Собрание законодательства Российской Федерации. - 2010. - № 18. - Ст. 2144; Постановление Пленума Верховного Суда Российской Федерации и Пленума Высшего Арбитражного Суда Российской Федерации от 23 декабря 2010 г. № 30/64 «О некоторых вопросах, возникших при рассмотрении дел о присуждении компенсации за нарушение права на судопроизводство в разумный срок или права на исполнение судебного акта в разумный срок» // Бюллетень Верховного Суда Российской Федерации. - 2001. - № 3.
}

\footnotetext{
8 См.: Стандарты справедливого правосудия (международные и национальные практики) / Под ред. Т.Г. Морщаковой. - М.: Мысль, 2012. - С. 134-145 (автор главы 1 М.А. Филатова); Никитина А.В. Разумный срок судебного разбирательства и исполнения судебных актов: практика получения справедливой компенсации: Монография / Отв. ред. С.В. Нарутто. - М.: Норма; ИНФРА-М, 2012. - С. 54-57.
} 
5. Сеньков А.А. Отложение и приостановление судебного разбирательства как общие условия: Автореф. дисс. ... канд. юрид. наук. - Челябинск, 2011.

6. Стандарты справедливого правосудия (международные и национальные практики) / Под ред. Т.Г. Морщаковой. - М.: Мысль, 2012.

\section{References}

1. Anoshina A.A. Priostanovlenie proizvodstva po grazhdanskim delam v sudakh obshchei yurisdiktsii: Avtoref. diss. ... kand. yurid. nauk. - Saratov, 2006.

2. Egorova M.S. Institut priostanovleniya proizvodstva po ugolovnomu delu i obespechenie prav i zakonnykh interesov uchastnikov ugolovnogo protsessa pri realizatsii ego norm: Avtoref. diss. ... kand. yurid. nauk. - Volgograd, 2003.

3. Ivanova E.A. Primenenie norm Konstitutsii Rossiiskoi Federatsii v grazhdanskom sudoproizvodstve: Avtoref. diss. ... kand. yurid. nauk. - M., 2009.

4. Nikitina A.V. Razumnyi srok sudebnogo razbiratel'stva i ispolneniya sudebnykh aktov: praktika polucheniya spravedlivoi kompensatsii: Monografiya / Otv. red. S.V. Narutto. - M.: Norma; INFRA-M, 2012.

5. Sen'kov A.A. Otlozhenie i priostanovlenie sudebnogo razbiratel'stva kak obshchie usloviya: Avtoref. diss. ... kand. yurid. nauk. - Chelyabinsk, 2011.

6. Standarty spravedlivogo pravosudiya (mezhdunarodnye i natsional'nye praktiki) / Pod red. T.G. Morshchakovoi. - M.: Mysl', 2012.

Материал поступил в редакцию 4 февраля 20142. 